
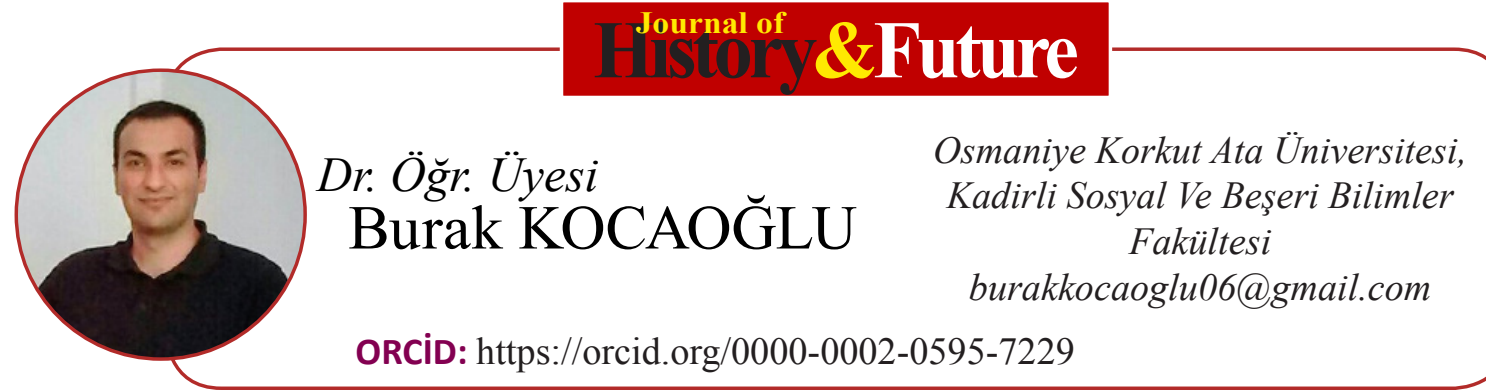

Eser Geçmişi / Article Past: 23 Haz 2019/24 Tem 2019

Araştırma Makalesi

DOI: http://dx.doi.org/10.21551/jhf.581380

Research Paper

Orjinal Makale / Orginal Paper

\title{
Osmanlı Devleti’nde Gemi Kazaları ve Devletin Kazalara Müdahale Usulleri (1763-1856)
}

\author{
Ship Accidents The Ottoman State and The State's Metohds Of \\ Intervention (1763-1856)
}

\section{Öz}

Osmanlı karasularında, devlete ait askeri ya da yerli ve yabancı tüccarlara ait birçok gemi çeşitli nedenlerden batmıştır. Yaklaşık olarak yüz yıllık süreç içerisinde Osmanlı karasularında meydana gelen gemi kazaları ve sonrasında yaşananlar üç başlıkta, ağırlıklı olarak Osmanlı arşiv kayıtları kullanılarak ele alınmıştır. Çalışmada ilk olarak deniz taşımacılığının avantaj ve dezavantajlarının neler olduğuna değinilmiştir. Devamında ise Osmanlı karasularında gemilerin hangi nedenlerden ötürü battığı, bunların kayıtlara nasıl geçtiği ve devletin, askeri veya sivil bir geminin battığına dair ihbarı almasının ardından göstermiş olduğu reaksiyon incelenmiştir. Bir diğer başlıkta ise kazazede olarak adlandırılan batıklardan çıkartılan malzemelerin türü ve malzemeler konusunda devletin tutumu tespit edilmeye çalışılmıştır. Bu noktada ağırlıklı olarak metal türünden askeri malzemeler ön plana çıkmış olsa da ticari gemilere ait malzemelerin çıkartılması ve sonrasında yaşananlar, yabancı devletlere verilen kapitülasyonlar merkezli ele alınmıştır. Çalışmanın son bölümünde ise gemi kazalarından sağ olarak kurtulan ya da ölmüş olan kişilerin yakınlarıyla devletin bir nevi sosyal güvenlik kapsamına giren ilişkisi genel çerçevede işlenmiştir.

Anahtar Kelimeler: Gemi, Batık, Dalgıç, Kapitülasyon, Tüccar.

ATIF: KOCAOĞLU Burak, "Osmanlı Devleti'nde Gemi Kazaları ve Devletin Kazalara Müdahale Usulleri (1763-1856)" Tarih ve Gelecek Dergisi, 5/2 (Ağustos-2019), s. (186-202) 


\begin{abstract}
Ottoman territorial waters, state owned military or domestic and forgein commericial ships have sunk various reasons. Our study, we tried to show the events that took place in Ottoman territorial waters and that ship accidents occurred, the following neraly one hunderds years, mainly based on the Ottoman arhives records. The first of what are the advantages and disadvantages of sea transport shown in a general contex. Later, for reasons which sank and how it goes on their record after receiving notification that the state of military or commerical ship has sunk, how the reaction showed. In another chapter of the study, the type of materials extracted from shipwrecks and the attitude of the state about materials were shown. At this point, even though the military materials were predominantly of metal type, the removal of the materials of commercial ships and the subsequent events were handled by the capitulations given to foreign states. In the last part of the study, the relationship between the relatives of the survivors or survivors of ship accidents and the state's entering into a kind of social security is discussed in the general framework.
\end{abstract}

Keywords: Ship, Wreck, Diver, Capitulation, Merchant.

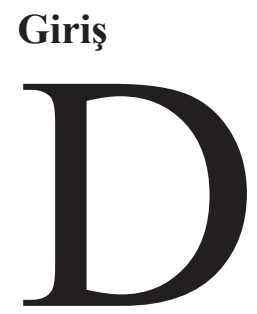

eniz taşımacılığ 1 tarihin her dönemine ulaşım alanında oldukça tercih edilmiştir. Deniz taşımacılığının tercih edilmesinde, insan ve hayvan gücüne dayalı sürdürülen kara taşımacılığına' göre daha hızlı, yük kapasitesinin daha yüksek olması ve buna paralel olarak da maliyetin düşük, kâr oranın daha yüksek olması gibi sebepler önemli rol oynamıştır. ${ }^{2}$ Ancak bu avantajlarına rağmen deniz taşımacılığı bünyesinde birçok riski barındırmıştır. Bu risklerin başında, düşman donanmasının veya korsan ${ }^{3}$ gemilerinin saldırıları gelmiştir. ${ }^{4}$ Ayrıca, denizcilerin coğrafi ve denizcilik bilgisinin yetersiz, gemi inşa teknolojisinin de tamamen ahşaba dayalı, nispeten ilkel sayılabilecek düzeyde yürütülmüş olmasi ${ }^{5}$ ve seyrüsefer sırasında olumsuz hava koşullarına her an tesadüf edilmesi, riski daha da arttırmıştır. Her ne kadar donanmaya ${ }^{6}$ veya tüccarlara ait gemiler Mayıs (Hızır) ayından

1 Suraiya Faroqhi, “Krizler ve Değişim 1590-1699”, Osmanlı İmparatorluğu’nun Ekonomik ve Sosyal Tarihi, C.2, (Edt. Halil İnalcık-Donald Quataert), Eren Yayıncılık, İstanbul, 2006, s. 610.

2 Kerim İlker Bulunur, "16. Yüzyılda Osmanlı İmparatorluğu’nda Deniz Taşımacılığı: Navlun ve İskerçe Sözleşmeleri”, History Studies, Volume 6-Issue 3, Nisan 2014, s.91.

3 Osmanlı Devleti'nde Müslüman korsanlar devletin koyduğu kurallar çerçevesinde denizlerde faaliyetlerini sürdürürlerse deniz gazisi olarak kabul edilmiş olup, yaptıkları faaliyet gaza olarak adlandırılmıştır. Şayet bir Müslümana ya da ahidnâme verilen devletin hedeflerine saldırı olursa o zaman harami olarak kabul edilmiştir. İdris Bostan, Adriyatik’te Korsanlık Osmanlılar, Uskoklar, Venedikler 1575-1620, Timaş Yayınları, İstanbul, 2009, s.20-21.

4 Mübahat Kütükoğlu, Balta Limanı'na Giden Yol Osmanlı - İngiliz İktisâdî Münâsebetleri (1580 1850), T.T.K., Ankara, 2013, s. 69-70.

5 Enver Ziya Karal, Selim III'ün Hat-tı Hümayunları Nizamı Cedit 1789-1807, T.T.K., Ankara, 1988. s.65.

6 Ali İhsan Gencer, Bahriye'de Yapılan Islâhât Hareketleri ve Bahriye Nezâreti'nin Kuruluşu (1789 - 1867), T.T.K., Ankara, 2001, s.169. 
başlayarak Kasım-Aralık ayları arasında deniz yolculuğuna çıkmış olsalar da gemi kazalarının önüne bir türlü geçilememiş ve gemi kazaları sıradan bir hal almıştır.

\section{Gemilerin Batmasına Neden Olan Unsurlar ve Devletin İlk Müdahalesi}

Osmanlı karasularında donanmaya ya da yerli ${ }^{8}$ ve yabancı tüccarlara ${ }^{9}$ ait çeşitli türden gemilerin batması kayıtlara çoğunlukla kazazede olan ${ }^{10}$ tabiriyle geçmiştir. Ancak kazazede ifadesi çok geniş kapsamlı olup gemilerin neden battığını tam olarak bizlere göstermemektedir. Bu noktada gemilerin batma sebeplerine baktığımızda karşımıza ilk olarak şiddetli firtınanın neden olduğu kazalar çıkmaktadır. ${ }^{11}$ Karadeniz (Bahr-i Siyah) ve Akdeniz (Bahr-i Sefid) sahil hattı boyunca meydana gelen batıkların büyük bir çoğunluğu şiddetli fırtına nedeniyle meydana gelmiştir. ${ }^{12}$

Batıkların bir diğer nedeni ise düşman saldırısıdır. ${ }^{13}$ Çoğunlukla savaş sırasında geminin isabet almas1 ${ }^{14}$ veya Çeşme faciasında görüldüğü üzere ateş kayıklarıyla gemilerin yakılmas $1^{15}$ sonucu, donanmaya ait birçok gemi batmıştır. Saldıran kuvvetin net olarak bilinmediği durumlarda ilk olarak hangi devletin saldırıda bulunduğu tespit edilmeye çalışılmıştır. ${ }^{16}$

7 Robert Mantran, 17. Yüzyılın İkinci Yarısında İstanbul, C.II, (Çev. M. Ali Kılıçbay-Enver Özcan), T.T.K., Ankara, 1990, s.185.

8 BOA.AE.SABH-I 236-15763., H.1195 (M.1781), Gelibolulu Süleyman Reis adlı kişinin Edremit’ten revgan-1 zeyt (zeytinyağı) yükleyip, İstanbul'a gelirken Erdek kazasına bağlı Kapıdağının Kocabergos karyesi sahilinde şiddetli fırtınaya yakalanıp kazazede olduğu, ancak bir miktar asel (bal) ve revgan-1 zeytin karaya çıkartıldığı belirtilmiştir. Karaya çıkartılan malların sevki için mektupla bir tüccarın görevlendirildiği, bu malların gümrük yasakçısı marifetiyle herhangi bir müdahale olmadan İstanbul'a gönderilmesi, Erdek kadısı ve Kapıdağı voyvodasından istenmiştir.

9 BOA. C.HR.60-2983., H.1232 (M.1817), Rusya tebaasından Covanni Barba adlı kişi, Nikola Reis adlı kişinin gemisine 1288 varil miktarındaki üzümünü kâr payı ortaklığıyla yükleyip İstanbul'a göndermeyi planlanmıştır. Ancak gemi firtınaya yakalanıp Biga'da kazazede olmuştur. / BOA. C.HR.7-311., H.1255 (M.1840), Rus gemi kaptanlarından Nikola Kaçya adlı kaptana ait geminin Aynaroz sahilinde kazazede olduğu, gemisinde İngiltereli bir bezirgana ait malların ve paranın olduğu belirtilmiştir.

10 BOA. C.AS.71-3333., H. 1212 (M.1797), Şile'de kazazede olan top sefinesinde bulunan askerlerin İstanbul'a getirildiği, bu askerlerin tekrardan yola çıkabilmesi için Mehmet Reis adlı kişinin gemisinin 200 kuruş navlun bedeliyle kiralanmıştır. Bahsi geçen kira bedeli İrad-ı Cedid hazinesinden ödenmiştir.

11 BOA. C.BH.97-4667., H.1242 (M.1826), İbrahim Paşa'nın (Mehmed Ali Paşa'nın oğlu) emriyle Muharrem Bey adlı kaptanın emrinde olan Mısır Donanmasından beş geminin Tunus Seraskeri Mehmet Kaptanın maiyetine verilip Navarin’e gönderildiği ve görev sırasında şiddetli fırtınaya yakalandığını, Fındık Ahmed adlı kaptanın Fal-ı Hayr adlı korvet türü gemisinin kazazede olduğu bildirilmiştir.

12 BOA.AE.SSLM-III 37-2129., H.1213 (M.1799) senesinde, Kütahya mütesellimi marifetiyle İzmir iskelesinden gönderilen askerlerin bulunduğu gemi, şiddetli fırtınaya yakalanıp, lenger halatlarını kesmelerine karşın kazazede olmuştur. Gemide bulunan askerlerin bir kısmı kayıklarla karaya çıkartılmış olup, daha sonra bu askerler başka yerlere firar etmiş̧ir. / BOA. C.BH.99-4751. H.1260 (M.1844) senesinde, Girit Adası sahillinde görevli olan Koçan isimli gemi şiddetli fırtınaya dayanamayarak batmıştır.

13 BOA. C.BH.21-1006., H.1205 (M.1791), Tuna'da bulunan 22 şaykadan 3 tanesi Moskovların İsmail'e hücumları sırasında kazazede olmuştur.

14 Daniel Panzac, Osmanlı Donanması (1572-1923), (Çev. Ahmet Maden-Sertaç Canpolat), İş Kültür Yayınları, İstanbul, 2018, s.282.

15 İsmail Hakkı Uzunçarşıllı, Osmanlı Devleti’nin Merkez ve Bahriye Teşkilâtı, T.T.K., Ankara, 1988, s.502.

16 BOA. C.HR.95-4716., H.1204 (M.1790), Ülgünlü Hüseyin Reis adlı kişinin gemisi Zanta Adası’nda 
Düşman tarafindan batırılan gemiler için nadiren de olsa gark olmak, yakılan gemiler için ise ihrak olunan ${ }^{17}$ ifadesi kullanılmış olsa da genellikle doğrudan kazazede ifadesi kullanılarak geminin batma hadisesi açıklanmaya çalışılmıştır. Ancak kayıtların tarihlerine baktığımızda batıkların en önemli nedeninin yaşanan savaşlar olduğunu rahatlıkla söyleyebiliriz. ${ }^{18}$ Ayrıca Osmanlı karasularında yaşanan haydutluk faaliyetleri sonucunda da bazı gemiler yakılıp batırılmıştır. ${ }^{19}$

Kazazede olarak tabir edilen geminin battığı bölgenin yöneticilerinden gelen haberle İstanbul' da bulunan yöneticiler harekete geçmiştir. ${ }^{20}$ İlk iş olarak, batığın bulunduğu bölgenin keşfi ve batığın çıkartılması işini organize etmek için ağırlıklı olarak donanmadan kaptanlar memur kılınmıştır. ${ }^{21}$ Ayrıca bölge yöneticilerinin de görevlendirilen kişilere yardımcı olunması emredilmiştir. Donanmadan görevlendirilen kişiler batığın bulunduğu bölgede keşif işlemini gerçekleştirip, batıklarda bulunan malzemelerin defterinin hazırlamas ${ }^{22}$ ve malzemelerin çıkartılıp İstanbul'a gönderilmesi ${ }^{23}$ için yanlarında arayıcı ağı ve mükemmel takımları bulunan sömbeki adı verilen dalgıçları götürmüşlerdir. ${ }^{24}$ Ağrılıklı olarak sünger çıkarmalarıyla meşhur olan Sömbeki Ceziresinden ${ }^{25}$

Venedik Donanması tarafından batırıldığı ifade edilmiştir. Ancak Venedikli General İmo adlı kişi, bahsi geçen geminin Venedik Donanması tarafından değil Moskov bandıralı gemi tarafından batırıldığını ifade etmiştir.

17 BOA. C.BH.102-4906., H.1185 (M.1771), İstanköy Adası karşında düşman tarafından ihrak olunan kalyona ait dört lengerin, Rodos Adası'nda inşa olan kalyonda kullanılması için gönderilmesi istenmiştir.

18 BOA. C.BH.213-9926., H.1184 (M.1771), Çeşme'de kazazede olan kalyonların, lenger, top ve gomona aletleri için çıkarılması için Hüseyin Kaptan adlı kişi görevlendirilmiştir. / BOA. C.BH.270-12490., H.1184 (M.1771), Çeşme Limanında kazazede olan donanmaya ait kalyonlara ait kebir lenger, top, gomona, çivi vs gibi malzemelerin, nakli için gerekli olan gemiler navlun bedeli belirlenerek tüccarlardan kiralanmış olup, ihtiyaç halinde yine tüccarlardan geminin kiralanıp navlun bedelinin İstanbul'da ödenmesi istenmiştir.

19 BOA. C.HR.50-2481., H.1214 (M.1799), Covani Andorya adlı Rus kaptana ait geminin, Devlet-i Aliyye hizmetinde olduğu, Akdeniz'de (Bahr-i Sefid) Kalamana bölgesinde firtınaya denk gelip lenger endaz etmeye (demir atmaya) mecbur kaldığı, ancak Mayna eşkıyasının gemideki tüm malları gasp ettikten sonra gemiyi yakarak (ihrak) batırdıkları belirtilip, suça karışanların tedibi ve zararın karşılanması Rus orta elçisi tarafından talep edilmiştir.

20 BOA. C.BH.123-5978., H.1187 (M.1773) Karadeniz'de kazazede olan donanmaya ait gemilerin top ve çeşitli mühimmatın denizden çıkartılmasının mümkün olduğu tespit edilip, denizden çıkartılan top ve mühimmatın güvenli bir yerde saklanması istenmiştir.

21 BOA. C.BH.246-11377., H.1202 (M.1787) senesinde, farklı mahallerde kazazede olan şalope türü 3 adet gemiye ait malzemelerin ve neferâtın nakliyesi için Bahr-i Siyah Boğaz Nazırı Mustafa Bey tarafından kiralanan boğaz kayıkları için toplam 120 kuruş, gark (batan) olan Moskovlu (Rus) sefinelerin keşfi için Tersane-i Âmire'den gönderilen iki kaptan için kiralanan gemiye 40 kuruş ve Moskovlulara ait gemilerden çıkartılan malzemelerin Tersane-i Âmire'ye nakli için 40 kuruş harcanmış olup, toplam bu işler için 200 kuruş ödenmiştir.

22 BOA. C.BH.201-9425.

23 BOA. C.BH.103-4972., H.1221 (M.1806), Korfa'ya gelirken Uzunada civarında kazazede olan Şevketnüma adlı fırkateyne ait top ve mühimmatların gönderilmesi işine Hüseyin Bey adlı kişi memur edilmiş olup, Hüseyin Bey gemiye ait alet edevatı karaya çıkarıp gönderilecek gemiyle alet ve edevatı İstanbul'a göndermiştir.

24 BOA. C.BH.7-317., H.1208 (M.1794), Anapa Kalesine gönderilen 14 büyük topu taşıyan gemi Samsun taraflarında batmıştır, batan geminin çıkartılması için Tersane-i Âmire emini İbrahim adlı kişi sorumlu kılınmış, iki nefer sömbeki tayinatları belirtilerek görevlendirmiştir. Sömbekiler buradaki görevleri bittikten sonra Sinop açıklarında batan gemilere ait lengerlerin çıkartılması için bölgeye gönderilmiştir. / BOA.AE.SSLM-III 116-7074.

25 Şenay Özdemir, “Osmanlı Denizciliğinde Gemi Kazaları ve Dalışlar”, OTAM, S.19, Ankara, 2006 , s. 373. 
dalgıçlar temin edilmiş olsa da özellikle donanmanın seferde olduğu ya da batık sayısının çok oldu$\breve{g u}$ facia zamanlarında dalgıçların çeşitli mahallerde görevlendirilmesine binaen ${ }^{26}$ Filyos gibi çeşitli bölgelerden de sömbeki temini yoluna gidilmiştir. Temin sırasında hangi bölgeden kaç sömbekinin alınacağı belirtilmiştir. ${ }^{27}$ Genellikle dalgıçların isimleri kayıtlara geçmemiş olsa da kimi zamanlar çıkartılacak malzemenin türüyle birlikte, dalgıcın adı da kayıtlara geçmiştir. ${ }^{28}$

Dalgıçlar önceden yeri belirlenen batığın bulunduğu konuma giderek geminin kaç kulaç derinlikte olduğunu belirleyip, hangi malzemelerin batıkta yer aldığını ve bu malzemelerin fiziki durumlarının nasıl olduğunu ayrıntılı bir şekilde belirlemişlerdir. ${ }^{29}$ Sömbekilerin, su altında çalışmasına dair Evliya Çelebi'nin seyahatnâmesinde kıymetli bilgiler yer almaktadır. Evliya Çelebi, seyahatnâmesinde, bunların her insanın yapamayacağı becerilerinin olduğunu, balık gibi yüzüp, yüz kulaç derinliğe dalarak batan gemilerden eşyaları eliyle koymuş gibi çıkardıklarını ${ }^{30}$, denizin dibini görebilmek için ağızlarına zeytinyağı alarak dalış yaptıklarını, dalış sırasında yağı bırakarak güneşin yansımasıyla denizin dibindeki iğneyi bile gördüklerini ifade etmiştir. Ayrıca bazı sömbekilerin iki taraflı bıçakla dalış yaptığını, bu bıçak sayesinde geminin halat vs. gibi malzemelerini kestiğini veya deniz dibinde bir balık ve timsah saldırısında kendilerini koruduğunu ifade etmiştir. ${ }^{31}$ Sömbekiler sadece donanma veya tüccarlara ait gemi batıklarının malzemeleri değil, savaş zamanında düşman kuvvetleri tarafından atılan çeşitli türden top ve metal malzemeleri de arayıp çıkarmak için görevlendirilmişlerdir. ${ }^{32}$

27 BOA. C.BH.213-9926., H.1184 (M.1771), Çeşme'de kazazede olan kalyonların, lenger, top ve gomona aletleri için çıkarılması için Hüseyin Kaptan adlı kişi görevlendirilmiş olup, batıklardaki bahsi geçen malzemelerin çıkartılması için Sömbeki Ceziresinden on ve Filyos'dan on, toplamda yirmi nefer nefer dalgıç Çeşme'ye gönderilmiştir. Çıkartılan malzemeler Boğazhisarında bekleyen üç direkli dört adet geminin birkaç sefer yapmasıyla İstanbul'a Tersane-i Âmire'ye nakledilmiş olup, gemilerin içinde bulunan leventlerin limana çıkmaları sadece gemide bahriyelilerin kalması istenmiştir

BOA. C.BH.220-10234., H.1221 (M.1806), Rus Kalbuk adlı dalgı̧̧ Karadeniz ve Tuna Nehrinde kazazede olan gemilerden kalma, lenger, tunç ve demir top, vs gibi malzemelerin çıkartılması için görevlendirilmiştir.

BOA. C.BH.123-5981., H.1202 (M.1787), Ruslara (Moskovlara) ait gemilerden bir tanesinin Rumeli'de Karaburun civarında İncek Mandırasında, bir tanesinin de Sakarya'da battığı belirtilip, İncek Mandırasında batan gemi için donanma kaptanlarından Kadri Kaptan, Sakarya'da batan gemi için Yusuf Kaptanın keşif için dalgıçlarla görevlendirildiği belirtilmiştir. Dalgıçlar İncek Mandırasında batan geminin 15 kulaç derinlikte olduğu belirtilip, mayıstıra sereni gibi parçaların sağlam kaldığı, top vs. gibi parçaların olmadığı ve hangi malzemelerin fırtınayla iki mil uzunluğunda sahil şeridine vurduğu belirtilmiştir. Sakarya'da batan geminin dalgıçlar tarafından yapılan incelemesi sonucunda geminin 5 kulaç derinlikte kuma saplanıp kaldığı, tirinkete sereni gibi parçalarının kaldığı ve ayrıca 9 kulaç derinlikte top gibi bazı malzemelerin olduğu belirtilmiştir.

30 Evliya Çelebi, Seyahatnâme (Akdeniz Adaları ve Girit Fethi), (Yay. Haz. İsmet Parmaksızoğlu), Kültür ve Turizm Bakanlığı Yayınları, Ankara, 1983, s.31-32.

31 Evliya Çelebi, Evliya Çelebi Seyahatnâmesi; İstanbul, 1.Cilt-2.Kitap, (Yay. Haz. Seyit Ali KahramanYücel Dağl1), Yapı Kredi Yayınları, İstanbul, 2004, s. 503-504.

32 BOA. C.BH.258-11927., H.1207 (M.1792), Suğla ve Anapa sahillerinde kazazede olan gemilere ait lenger, top vs. malzemelerin denizden çıkartılması dışında, Moskovlar (Ruslar) tarafından atılan, top, humbara ve çeşitli güllenin denizden çıkartılması için üç nefer sömbeki, bir kıta fener kayığı, arayıcı ağ1 ve mükemmel takım ile gönderilmesi istenmiştir. Ancak sömbeki neferlerinin donanmayla birlikte Akdeniz'de (Bahr-i Sefid) olduğu ifade edilmiştir. 


\section{Batıklardan Çıkartılan Malzemeler} liriz.

Batıklardan çıkartılan malzemeleri askeri ve ticari malzemeler olarak iki ana gruba ayırabi-

\section{1. Askeri Malzemeler}

Askeri malzemelerin başında, deniz dibinde uzunca süre herhangi bir şekilde bozulmadan kalabilen çeşitli türden top ${ }^{33}$, lenger, çivi vs. gibi metaller ${ }^{34}$, çeşitli istihkâm malzemeleri ${ }^{35}$ ve geminin tahta kısımlarına ait bazı parçalar ${ }^{36}$ yer almıştır. Genellikle hafif malzemeler deniz yüzeyinde kalıp kıyıya vurmuş olsa da ağır metaller deniz tabanına oturmuştur. Bu şekilde deniz tabanına oturan malzemelerin denizden çıkartılması işlemi kayıtlara genellikle taşraya çıkartma olarak düşülmüştür. ${ }^{37}$ Devrin imkânları dâhilinde malzemelerin tamamına ulaşılması ve çıkarılması pek kolay olmamış ${ }^{38}$ kimi zaman malzemeler batığın bulunduğu alan dışında, uzunca bir sahil hattı boyunca yayılmıştır. ${ }^{39}$ Merkezi devlet, yeleri tespit edilen malzemelerin ne pahasına olursa olsun denizden çıkarılarak bunların İstanbul'a gönderilmesini çoğu kez özellikle telkin etmiştir. ${ }^{40}$ Şayet tespit edilen malzemelerden birinde eksiklik olursa, bölge yöneticilerine malzemenin çıkartılması konusunda tekrardan emir gönderilmiştir. ${ }^{41}$

33 Yusuf Alperen Aydın, Sultanın Kalyonları Osmanlı Donanmasının Yelkenli Savaş Gemileri (17011770), Küre Yayınları, İstanbul, 2011, s.340-341.

34 BOA.AE.SSLM-III 116-7074., H.1212 (M.1797), Halil Kaptan adlı kişinin emrinde olan donanmaya ait bir fırkateyn ve bir kırlangıç türü geminin Kapıdağı tarafında battığı, bu gemilerden kalan top ve çeşitli malzemenin denizden çıkartılması için harcırahları tersaneden verilen, Hacıoğlu Mehmed Çavuş ve iki nefer reis ile birlikte bir sömbeki görevlendirilmiştir. Daha öncesinden 22 kıta top ve 7 lenger demiri tersaneye gönderilmiş olup, firkateyne ait 1,5 vukıyyeelik tunç top ve 1,5-2 vukıyyelik beş demir top, Yakup Reis adlı kişinin gemisiyle Tersane-i Âmire’ye gönderilmiştir.

35 BOA. C.AS.1218-54653.

36 BOA. C.BH.29-1380., H.1255 (M.1840), Şile açıklarında kazazede olan gemide Tersane-i Âmire'nin malı olup karaya çıkartılan 150 kıtadan fazla sal ağacının Şile ahalisi tarafından gönderileceği belirtilmiş olsa da, bir tanesinin bile gönderilmediği belirtilip, sal ağaçlarının Tersane-i Âmire'ye nakli için ağaçların boyutuna ve ağırlığına göre kayıkların temini istenmiştir.

37 BOA. C.BH.258-11927.

38 BOA. C.AS.1218-54653., H.1252 (M.1836), İskenderiye Ülgün, Bar ve Draç kalelerinin istihkamı için lazım olan malzemeler denizyoluyla İstanbul'dan gönderilmek istenmiştir. Ancak Gaston bölgesinde gemi kazazede olup, malzemelerin büyük bir kısmının telef olduğu, kalan kısmın Preveze cephanecibaşı tarafından teslim alınıp saklandı̆̆ bildirilmiştir.

39 BOA. C.BH.84-4017., H.1190 (M.1776), Karadeniz'de (Bahr-i Siyah) kazazede olan gemilere ait top, lenger ve bazı malzemelerin Varna, Ağaçlı, Ormanlı, Süzebolu ve Midye sahilleri civarında görüldüğü belirtilip, denizden çıkartılan malzemelerin tüccar gemilerine yüklenip İstanbul'a gönderilmesi istenmiştir.

40 BOA. C.BH.86-4136., H.1196 (M.1782), Dimyat Limanına demirlemiş olan gemilerin şiddetli fırtına nedeniyle battığı, üç adet sağir ve kebir topun çıkarılıp gönderilmesi istenmiş, ancak bir adet kebir topun denizden çıkarılması mümkün olmamıştır. Kalan bu topun ne yapılıp edilip çıkartılması istenmiştir.

41 BOA. C.BH.219-10198., H.1214 (M.1799) senesinde, Gaston sahilinde kazazede olan şalope türü geminin top, halat vs. gibi malzemelerinin denizden çıkartılıp, Rusyalı bir tüccara ait kırlangıç türü gemiyle malzemelerin tersaneye gönderildiği ancak gemiye ait lengerin denizden çıkartılamadığı için gönderilememiştir. Bu durum üzerine denizde kalan lengerin ne yapıp edip çıkartılıp, Tersane-i Âmire’ye gönderilmesi Mora valisinden istenmiştir. 
Batıklardan çıkartılan önemli askeri malzemelere bakacak olursak karşımıza ilk olarak lenger çıkmaktadır. Lenger, her türden gemide, geminin türüne ve ebadına göre çeşitli sayıda kullanılan, gemilerin deniz üzerinde veya limanda sabit kalmasına yarayan büyük demirdir. ${ }^{42}$ Lenger yapımının masrafl1 ${ }^{43}$ ve uzun mesai gerektiren bir iş olmasi ${ }^{44}$ nedeniyle devlet, şiddetli fırtına, düşman tarafından yakılma ya da batırılma veya yaşanan bir kaza sonucu batmış olan gemilerden çıkartılan lengerleri, yeni inşa olunan ya da bakım ve onarımı yapılan gemilerde sıklıkla kullanma yoluna gitmiştir. ${ }^{45} \mathrm{Bu}$ nedenle batığa ait lenger ve benzeri metal malzemelerin çıkartılıp İstanbul'a Tersane-i Âmire mahzenine gönderilmesi ${ }^{46}$ için batığın olduğu bölgeye malzemenin çıkartılması işiyle meşgul olacak görevliler gönderilmiştir. ${ }^{47}$

Batıklardan çıkartılan diğer bir önemli askeri malzeme de çeşitli boyut ve türdeki toplardır. ${ }^{48}$ Genellikle geminin üstünde bulunan ${ }^{49}$ ya da bir bölgenin güvenliğinin sağlanması için ${ }^{50}$ veya ordunun bulunduğu cepheye gönderilmesi istenilen toplar, Tophane-i Âmire'den gemilere yüklenerek istenilen yere nakli amaçlanmıştır. ${ }^{51}$ İçerisinde veya üzerinde top bulunan geminin yukarıdaki nedenlerden ötürü batmasıyla bu ağır metaller deniz tabanına oturmuştur. Kimi zaman bu malzemelerin çıkartılması mümkün olmamış ya da devletin görevlendirdiği memurlardan önce kaza mahalline varan ahali batıklardaki topları çıkararak çeşitli mahallere satmışlardır. Devlet bu gibi durumların yaşanmaması için gerektiğinde komşu devletlerle, batıklara ait malzemelerin çıkartılması konusunda iş birliği yoluna gitmiş ${ }^{52}$ olsa da, çoğu kez malzemelerin başkalarının eline geçmesini

42 Mehmet Zeki Pakalın, “Lenger”, Osmanlı Tarih ve Deyimler Sözlüğü, C.2, Milli Eğitim Basımevi, İstanbul, 1983, s. 358.

43 BOA. C.BH.63-2970., H.1176 (M.1763) Sinop’ta donanma kalyonlar için gerekli olan büyük lengerlerin bazıları tamir olunup kullanıma hazır hale getirilmesi istenmiştir. Buna neden olarak yapılacak olan lengerlerin masrafının çok olacağından bunun için tersanede bulunan batıklardan alınan 4 adet lengerin tamir edilmesi düşünülmüştür. Yapılacak işlemler sonunda (bir lengerin iki kıta yaprağı, ikisinin tırnak ve halkalarının tamiri) 160 kuruş tamir masrafı olacağı belirtilmiştir.

44 BOA. C.BH.152-7252., H.1182 (M.1768), Tersane-i Âmire'de inşa olunan iki adet kalyonun her biri için 35 kantardan 3 adet lenger gerektiği, tersanede hazır lenger olmadığından, tersane demirhanesinde ihtiyaç duyulan lengerlerin Kigork adlı zimmi usta vasıtasıyla yapılması kararlaştırılmıştır. Yapılacak lengerlerin her birinin 25 gün içerisinde tamamlanacağı belirtilmiştir.

BOA. C.BH.2-60., H.1185 (M.1772) senesinde Sinop’ta inşa olunan iki kalyonda kullanılmak üzere kazazede olan gemilerin lengerleri beş-on gün zarfında kaptan paşadan istenmiştir. Lengerler donanmaya ait mahzende saklanmış olup, on iki kıta olup kebir olarak adlandırılan büyük çapta lengerlerdir. BOA. C.BH.111-5384., H.1222 (M.1807) senesinde Karadeniz'de batan donanma kalyonlarına ait lenger, cıvata gibi türden malzemenin toplanarak Tersane-i Âmire'ye teslim edilmesi bölge yöneticilerinden istenmiştir. olan (suya batan) gemilere ait, lenger, top ve çeşitli demir malzemelerin çıkartılması için görevlendirilenle gidecek olan çuhadara 500 kuruş verilmiştir. / BOA. C.BH.258-11927. gemilere yerleştirilen top sayısında artış yaşanmıştır. Tuncay Zorlu, Osmanlı ve Modernleşme III. Selim Dönemi Osmanlı Denizciliği, Timaş Yayınları, İstanbul, 2014, s.123-124. İdris Bostan, Osmanlılar ve Deniz (Deniz Politikaları-Teşkilât-Gemiler), Küre Yayınları, İstanbul, 2017, s.176-177.

50 BOA. C.AS.1204-53925., H.1220 (M.1805), eşkıya takibi için Tophane-i Âmire'den mühimmat yüklenip Tekfurdağı'na gönderilen geminin kazazede olduğu, kazazede olan gemiden kalan mühimmatın tespiti için defter hazırlanması bölge yöneticilerinden istenmiştir.

51 BOA. C.BH.7-317., H.1208 (M.1794), Anapa Kalesine gönderilen 14 büyük topu taşıyan gemi Samsun açıklarında batmıştır. 
önleyememiştir. Ancak olayın üstünden uzunca bir zaman geçse bile batıklara ait malzemelerin çıkartıldığı veya satıldığı ihbarı alınırsa, derhal bahsi geçen batığa ait malzemelerin tespiti yoluna gidilip, devletten izinsiz batıklara ait malzemeleri çıkartıp satanların İstanbul'a gönderilmesi ve malzemelerin tazmini bölge yöneticilerinden istenmiştir. ${ }^{53}$ Bunun dişında batıklardan malzemeleri çıkartan ve muhafaza edip görevlilere teslimini sağlayan askeri ve sivil kişilere yaptıkları çalışmanın başka kişilere örnek olması ${ }^{54}$ ve mükâfatlandırılması için çeşitli miktarda ihsanda da bulunulmuştur.

Lenger, top ve çeşitli metal malzemelerin denizden çıkartılma işleminin tamamlanmasından sonra kayıt defterleri tutulup ${ }^{55}$, malzemelerin gerekli bakım ve onarımlarının yapılıp tekrardan kullanıma hazır hale getirilmesi için İstanbul'a, Tersane-i Âmire ve Tophane-i Âmire'ye gönderilmesi gerekmiştir. ${ }^{56} \mathrm{Bu}$ noktada malzemelerin istenilen şekilde İstanbul'a nakli için malzemenin ağırlığ 1 ve miktarına uygun bir geminin seçilmesi gerekmiştir. ${ }^{57}$ Nadiren de olsa batığının bulunduğu bölgenin ileri gelenlerine malzemelerin gönderilmesi ${ }^{58}$ işi verilmişse de çoğunlukla nakliye sırasın-

Tersane-i Âmire ve Humbarahaneden malzeme götüren geminin Selene Limanı denilen yerde kazazede olduğu ve büyük miktarda malzemenin onun bunun eline geçmeden İstanbul’a gönderilmesi için Yunan tarafıyla iş birliği yapılması istenmiştir.

53 BOA. C.BH.2-67., H.1212 (M.1797) senesinden sekiz sene önce Ağrıboz’a bağlı Kızılhisar bölgesinde kazazede olan donanmaya ait fırkateynin toplarının denizden çıkarılmasının mümkün olmadı̆̆ı, ancak ilerleyen zamanda Çeşme ve civarından bazı zimmi ve Müslüman reislerin gelerek 14 kayıkla denizde kalan 24 topu çıkarıp Ahmet Kaptan adlı kişinin gemisiyle Mısır’a sattıkları belirtilmiştir. Belgede hangi kaptanın kaç topu çıkardığı (Cafer ve Mustafa Kaptanlar üçer) belirtilip, konuda bahsi geçen reisler ve kişilerden topların parasının alınması ve kişilerin İstanbul'a gönderilmesi Çeşme naibinden istenmiştir.

54 BOA. C.BH.2-46., H.1234 (M.1819), Karadeniz'de Karaburun açıklarında bulunan iki topun çıkartıldığı, çıkartılan bu topların Cezayirli Gazi Hasan Paşa (1789-1790) döneminde batan gemilere ait olduğu belirtilip, bu topların gönderilmesi için gerekli olan kayık, çavuş ve neferat ücretinin 2000 kuruş tuttuğu, bunun dışında bu şekilde batık olan top ve lengerin çıkartılmasında gayret ve çaba göstermiş olan çavuş ve neferlerin teşviki için ihsan olunacak bedel ne kadarsa, hizmeti geçenlere verilecek olan bedelinde toplam masrafa dahil edilmesi istenmiş olup, tersane hazinesinden 500 kuruş ihsanda bulunulmuştur.

55 BOA. C.BH.201-9425., H.1219 (M.1804), Rodos Adası'nda Hasan Bey adlı kişi tarafından inşa olunan ve Ağustos ayında denize indirileceğinden bahsedilen kalyon için Tersane-i Âmire ve çeşitli mahallerden gönderilen malzemeden başka, Ali Çavuş adlı kişi tarafından defteri tutulmuş olan kazazede bir birik türü gemiden çıkartılan demir top vs. gibi malzemelerin kayıkla gönderilmesi istenmiştir

BOA. C.BH.206-9622., H.1218 (M.1804), Anapa’ya gönderilen ancak Sakarya açıklarında kazazede olan ve İstanbul'dan gönderilen mübaşir vasıtasıyla tamir için İstanbul'a getirilecek olan kırlangıç türü bir geminin tamir masrafı Altıkulaçzade Hüseyin Efendi’nin uhdesinde olan miri gelirden karşılanması istenmiştir.

57 BOA. C.BH.36-1686., H.1222 (M.1807) Siderkapısında kazazede bir kalyon ve iki firkateyne ait lengerlerin ve topların çıkartılıp tersaneye gönderilmesi Selanik kadısı ve müftüsünden istenmiştir. Ancak bu malzemelerin ağırlığın fazla olmasından sandallarla naklinin zor olacağı ifade edilip, bunların başka bir araçla gönderilmesi istenmiştir.

58 BOA. C.BH.273-12612., H.1207 (M.1792), Karadeniz'de Filyos civarında kazazede olan kalyona ait toplardan yedisinin nakli için dört gemi Amasra'da bulunan rüesaya taksim edilmiş olup, bu kişilerin işi ertelediği belirtilip, bahsi geçen topların ve kalan diğer malzemelerin acilen İstanbul'a Tersane-i Âmire'ye gönderilmesi emredilmiştir. 
da kullanılacak olan gemiler Gayrimüslim ${ }^{59}$ ve Müslim kaptanlardan (tüccarlardan) kiralanmıştır. ${ }^{60}$ Kiralamalarda geminin navlun bedeli ${ }^{61}$ yüklenecek malzemenin ağırlığına (kantar) ve geminin kapasitesine göre hesaplanarak, gerekli şartların belirtildiği mukavele ilgili kaptanla düzenlenmiştir. ${ }^{62}$ Düzenlenen mukavelelerde kiralama işlemi sırasında gemi kaptanının kim olduğu, hangi türden, kaç geminin, hangi navlun bedeli üzerinden kiralandığı ayrıntılı bir şekilde belirtilmiştir. ${ }^{63}$

\section{2. Ticari Malzemeler}

Osmanlı karasularında ${ }^{64}$ yerli ve yabancı (Rus, Nemçe, İngiliz, Fransız ve Felemenk) birçok tüccar ve kaptan faaliyet göstermiştir. ${ }^{65}$ Bu kişilerin gemilerine yükledikleri ürünler çeşitlilik arz etmiştir. Osmanlı deniz ticareti haritasına baktığımızda en yoğun ticari faaliyetin İstanbul ve çevresinde gerçekleştiğini görürüz. ${ }^{66}$ İstanbul'un çeşitli ihtiyaçlarının karşılanması için gerekli olan malzemeler, gerek geniş Osmanlı coğrafyasından ${ }^{67}$ gerekse başka ülkelerden gemilerle getirilmiştir. ${ }^{68}$

59 BOA. C.BH.84-4005., H.1188 (M.1775), donanmaya ait kalyonların Çeşme'de kazazede olduğu, gemilerden kalan top vesaire malzemenin, Tophane ve Tersane-i Âmire mahzenlerine gönderilmesi için kantarı 40 akçeden olmak üzere 1000 kuruşa Aydınlı Yorgi adlı zimmi reisin gemisi kiralanmak istenmiştir. Ancak bahsi geçen kaptan, kendi gemisinin navlunun 1500 kuruş olacağını belirtmiştir.

60 BOA. C.AS.71-3333., H. 1212 (M.1797), Şile'de kazazede olan top sefinesinde bulunan askerlerin İstanbul'a getirildiği, bu askerlerin tekrardan yola çıkabilmesi için Mehmet Reis adlı kişinin gemisinin 200 kuruş navlun bedeliyle kiralanıp, kira bedeli İrad-ı Cedid Hazinesinden ödenmiştir.

61 Gemiye alınan yük için mal sahibinin gemi sahibine ödediği taşıma bedeli.

62 BOA. C.BH.270-12490., H.1184 (M.1771) tarihli belgede, Çeşme Limanında kazazede olan kalyonlara ait kebir lenger, top, gomona, çivi vs gibi malzemelerin, nakli için gerekli olan gemiler navlun bedeli belirlenerek tüccarlardan kiralanmış olup, ihtiyaç halinde yine tüccarlardan geminin kiralanıp navlun bedelinin İstanbul'da ödenmesi istenmiştir.

63 BOA. C.BH.124-6014., H.1186 (M.1773), Çeşme'de batırılan donanmaya ait gemilere ait lenger, demir aletleri ve benzeri gibi malzemelerin toplanıp İstanbul'a nakledilmesi istenmiş olup, bu iş için Gayrimüslim reislerden iki gemi kiralanmıştır. Gemilerden birine 1500 birine de 1200 kuruş olmak üzere 2700 kuruş navlun ödenmiştir.

64 Akdeniz'de Fransız, İngiliz ve Felemenk gemilerinin yoğun bir şekilde faaliyet göstermelerine karşın Karadeniz’e XVIII. yüzyılın sonlarına kadar yabancı gemilerin girmesi çok nadir olmuştur. Ruslarla yapılan savaşlar ve kayıplar sonrasında Rus bandıralı gemiler Karadeniz'de sıklıkla görünmeye başlamışlardır. Mübahat Kütükoğlu, Osmanlı’nın Sosyo-Kültrüel ve İktisâdî Yapısı, T.T.K., Ankara, 2018, s.391.

65 BOA. C.HR.25-1240., H.1209 (M.1795), Fransız, Dupon adlı kaptanın gemisiyle İskenderiye'den Tunus'a götürmek için hacıları aldığı ancak Anamur civarında kaptana ait geminin kazazede olmuştur. Kazazede olan gemiden 13,847 kuruşluk eşya ve iki adet lenger, iki adet yelken ve altı adet tüfek karaya çıkartılmıştır. Bahsi geçen malzemelerin dışında tüm malzemelerin gemiyle birlikte battığına dair bölge kadısının ilamı ve İçil Mutasarrıfı Yusuf Paşa’nın inhası gözükmektedir.

66 Donald Quataert, “19. Yüzylla Genel Bakış: Islahatlar Devri 1812-1914”, Osmanlı İmparatorluğu'nun Ekonomik ve Sosyal Tarihi, C.2, (Edt. Halil İnalcık-Donald Quataert), Eren Yayıncılık, İstanbul, 2006, s.920.

67 Mehmet Genç, Osmanlı İmparatorluğunda Devlet ve Ekonomi, Ötüken, İstanbul, 2014, s. 57.

68 BOA. C.BH.133-6446., H.1239 (M.1824), Boğdan Voyvodası tarafından kalyon ve zindan firınları için gönderilecek olan hıntanın (buğday) Kalas iskelesinden Abdi Kaptan ve Hacı Hasan Kaptan adlı kişilerin gemilerine yüklenip iki makbuz hazırlanmıştır. Abdi Kaptanın 5690 kile hınta yüklü gemisinin tersaneye yükünü boşaltmıştır. Ancak Hacı Hasan Kaptanın gemisi Midye açıklarında kazazede olmuştur. Kazazede olan gemiye yüklenen toplam hınta miktarı 7250 kile olup kilesi 82 paradan toplam bedeli 14.862,5 kuruş etmiştir. Bu miktarın 4954 kuruş 7 parası tenzil olunup, geriye kalan 9908 kuruş 13 para ödenmiştir. Ayrıca Abdi Kaptanın getirdiği hıntanın 11.660,5 kuruş bedeli de Tersane-i Âmire 
Kimi zaman bu gemiler genellikle şiddetli firtına nedeniyle İstanbul'a gelmeden batmıştır. Batan gemilerdeki malzemeler arasında, revgan-1 zeyt (zeytinyağı), asel (bal) ${ }^{69}$, hınta (buğday) ${ }^{70}$, üzüm ${ }^{71}$ gibi gıda maddeleri dışında, yapağ $1^{72}$, çeşitli türden kumaş, bez, iplik ve kum saati ${ }^{73}$ gibi emtialar yer almıştır. Ayrıca, gemi mürettebatı ya da yolcularına ait para ve kişisel eşyalar batıklar içerisinde yer alan diğer ticari nitelikli malzemelerdendir. ${ }^{74}$

Bahsi geçen malzemelerin sahibi tespit edilebilirse eksiksiz bir şekilde sahibine teslimi gereklidir. ${ }^{75}$ Ancak bu durum yerel yöneticiler ve görevliler tarafından pek dikkate alınmamıştır. Bu sebepten batıktan çıkartılan malzemelerin sahipleri, malzemelere gümrük yasakçıları tarafından bir müdahalede bulunulmamasını talep etmişlerdir. ${ }^{76}$

Özellikle diş ticaret hacminin arttığı ve kapitülasyonların ${ }^{77}$ etkisinin hissedilmeye başlandığ XIX. yüzyılın ikinci çeyreğinden itibaren gemi batıklarından çıkartılan malzemeler konusu ayrı bir boyuta taşınmıştır. Yabancı gemi kaptanları ve tüccarları müstemin ${ }^{78}$ statüsünde Osmanlı karasularında faaliyet göstermişler ve Osmanlı limanlarına hiçbir mani olmaksızın sığınıp ihtiyaçlarını karşılayabilmişlerdir. ${ }^{79}$ Bunlara ek olarak gerçekte Osmanlı tebaası olup, ancak çeşitli vergilerden ve yükümlülüklerden kurtulmak için ${ }^{80}$ bir fırsatını bularak başka bir devletin tabiiyetine ve koruyuculuğuna girenler olmuştur. ${ }^{81}$ Bahsi geçen kişiler, tebaası olup ya da tebaası olduklarını iddia ettikleri devlete, Osmanlı Devleti tarafından verilen ahidnâmeler sayesinde Osmanlı karasularında

Hazinesinden ödenmiştir.

69 BOA.AE.SABH-I 236-15763.

70 BOA. C.BH.133-6446.

71 BOA. C.HR.60-2983.

72 BOA. C.HR.98-4873.

73 BOA. C.HR.18-864.

74 BOA. C.BH.104-5033., H.1275 (M.1858), Alanya Sancağına bağlı Düşenbe nahiyesine müdür olarak görevlendirilen Tahir Bey adlı kişinin, oğluyla birlikte vapurla Antalya Limanına gelip ve buradan da Alanya'ya kayıkla geçmek istediğini ancak çıkan fırtına sonucu kayığın batıp, kendi memuriyetine ait belgelerinde de içerisinde bulunduğu eşyasının zayi olduğu bildirilmiştir.

75 İdris Bostan, Osmanlı Bahriye Teşkikâtı: XVII. Yüzyılda Tersâne-i Âmire, T.T.K., Ankara, 2003, s.152.

76 BOA.AE.SABH-I 236-15763., H.1195 (M.1781), Gelibolulu Süleyman Reis adlı kişinin gemisine Edremit’ten revgan-1 zeyt (zeytinyağı) yükleyip, İstanbul'a gelirken Erdek kazasına bağlı Kapıdağının Kocabergos karyesi sahilinde şiddetli fırtınaya yakalanıp kazazede olmuştur. Ancak bir miktar asel (bal) ve revgan-ı zeytin karaya çıkartıldığı belirtilmiştir. Karaya çıkartılan malların sevki için mektupla bir tüccarın görevlendirildiği, bu malların gümrük yasakçısı marifetiyle herhangi bir müdahale olmadan İstanbul'a gönderilmesi için Erdek Kadısına ve Kapıdağı Voyvodasına emirler gönderilmiştir.

77 Osmanlı Devleti’nden kapitülasyon alan bazı ülkeler ve tarihleri şöyledir, Avusturya 1615, Hollanda 1680, İsveç 1737, Sicilya 1740, Danimarka 1746, Prusya 1761, İspanya 1782, Rusya 1783, Sardunya 1823, A. B. D. 1830, Belçika 1838, Portekiz 1843, Yunanistan 1855, Brezilya 1858, Niyazi Berkes, Türkiye İktisat Tarihi, Yapı Kredi Yayınları, İstanbul, 2013, s.186.

78 Verilmiş olan ahidnâmeler sayesinde Osmanlı coğrafyasında ticari faaliyet gösteren başka devlet tebaaları kayıtlara müstemin olarak geçmiştir.

79 Mübahat Kütükoğlu, “Osmanlı İktisadî Yapısı”, Osmanlı Devleti Tarihi, C.2, (Edt. Ekmeleddin İhsanoğlu), IRICA, İstanbul, 1999, s. 597.

80 Ali İhsan Bağış, Osmanlı Ticaretinde Gayri Müslimler, Turhan Kitabevi, Ankara, 1983, s. 87.

81 Bu kişiler konsoloslardan berat ve patent alarak kapitülasyonlarla tanınmış olan ayrıcalıklardan faydalanmışlardır. Mahmi sorunu olarak da bilinen bu sorunu daha detaylı görmek için bknz. Gülnihal Bozkurt, Azınlık İmtiyazları- Kapitülasyonlardan Tek Hukuk Sistemine Geçiş, ATAM., Ankara, 1998. 
rahatlıkla ticari faaliyetlerini sürdürebilmişlerdir. Bu kaptan ve tüccarlar, Osmanlı karasularında gemileri battığında artık doğrudan Osmanlı Devleti'ne değil, verilen ahidnâmelere dayanarak ${ }^{82}$, tabiiyetinde oldukları devletin ${ }^{83}$ ya da başka bir devletin elçileri ve konsolosları vasıtasıyla ${ }^{84}$ veya çeşitli aracılarla malzemelerini kolaylıkla alma yoluna gitmişlerdir. ${ }^{85} \mathrm{Bu}$ durum, Osmanlı Devleti'nde bulunan konsolos, konsolosluk çalışanları ve yakınları için önemli bir gelir kapsı halini almıştır. ${ }^{86}$ Diğer taraftan olaya tüccar ve kaptanlar açısından bakarsak, kişilerin bu yolu seçmesinde şüphesiz batığın bulunduğu bölge yöneticilerinin batıklara ait malzemeleri sahibine teslimi konusunda çıkardıkları sorunların etkili olduğunu belirtebiliriz. ${ }^{87}$

\section{Gemi Kazaları Sonrası Devletin Yükümlülükleri}

Yaşanan gemi kazalarından sonra devletin bazı yükümlülükleri doğmuştur. Bu yükümlülüklerin başında, devlet için malzeme getiren ancak kazazede olan gemilerdeki yükün bedelinin karşılanması gelmiştir. ${ }^{88}$ Devlet genellikle, denizde heba olan malzemenin miktarını ve bedelini belirleyip ${ }^{89}$, gemi kaptanıyla yapılan mukavelenin incelenmesi sonrasında karşı tarafin zararını karşılamıştır. ${ }^{90} \mathrm{Bu}$ sayede bir nevi sigortacılık faaliyetlerinin gelişmesine kadar geçen sürede devlet,

82 BOA. C.HR.4-193., H.1254 (M.1839) tarihinde Rus sefaretinden gelen bir takrirde, Rus tebaası olan, Marich adlı kişinin kaptanı olduğu geminin Karaburun'a geldiğinde şiddetli firtına nedeniyle kazazede olduğu, geminin karaya çıkartılan hamulesi ve çeşitli malzemelerinin Antonyon adlı kişiye teslim edilmesi ahidnâme gereğince istenmiştir.

83 BOA. C.HR.60-2983., H.1232 (M.1817), Rusya tebaasından Covanni Barba adlı kişi, Nikola Reis adlı kişinin gemisine 1288 varil üzümü kâr payı ortaklığıyla yükleyip İstanbul'a göndermiştir. Ancak gemi fırtınaya yakalanıp Biga'da kazazede olmuştur. Kazazede olan gemiden 980 varil üzümün Güvercinlik olarak da bilinen Dimetoka'da karaya çıkartıldığı belirtilip, bahsi geçen miktarın Dimetoka voyvodası Çelebizade Halil tarafından alındığı buna binaen Kocaeli ve Hüdavandigar Mutasarrfı vasıtasıyla H.1230 senesi, Muharremin yedinci gününden itibaren 61 günlük süre içerisinde ödenmek şartıyla 6000 kuruşluk bir temessük verildiği ancak Çelebizade Halil tarafından herhangi bir ödemenin bir seneye aşkın süredir yapılmadığı, Rus orta elçisi tarafından bildirilmiştir.

84 BOA. C.HR.18-864., H.1255 (M.1839), Kukoş sahilinde kazazede olan iki Fransız ve bir Nemçe (Avusturya) ticaret gemisinden çıkartılan eşyaların, Felemenk konsolosu Frobonari? adlı kişinin kefaletiyle alınmıştır. Nemçeli Tomazo ve Fransız Comlo ve Gobarlok? adlı kaptanların eşyalarının neler olduğu deftere kaydedilmiştir. Deftere kaydedilen eşyalar arasında çeşitli türden bez, iplik, barut, kum saati gibi eşyalar mevcuttur.

85 BOA. C.HR.7-311., H.1255 (M.1840), Rus gemi kaptanlarından Nikola Kaçya adlı kaptana ait gemi Aynaroz sahilinde kazazede olmuştur. Gemide İngiltereli bir bezirgana ait malların ve paranın olduğu belirtilmiş̧ir. Selanik mutasarrıfı, Aynaroz muhafızı, tayin kılınan bir memurun vasıtasıyla mal ve paranın tespitinin yapıldığı ve kaptanın oğlunun, vekili olan Nemçe konsolosunun kardeşi Domniko adlı müstemine bütün eşya ve paranın teslim edilip makbuzunun alındığını, herhangi bir eşya ve alacaklarının kalmadığını ancak İngiltere konsolosunun malların teslim edilmediğini ifade etmesi üzerine, malların bahsi geçen kişiye teslim edildiği buna dair makbuzun olduğu belirtilmiştir.

86 Burak Kocaoğlu, Osmanlı Devleti'nde Cizye Vergisi, Berikan Yayınevi, Ankara, 2018, s. 47.

87 BOA. C.HR.98-4873., H.1248 (M.1832), Rusyalı Fedor Ocenkof? adlı kaptanın, Taygan iskelesinden yapağı ve çeşitli malzemeleri yükleyip İstanbul'a gelirken, Karadeniz'de firtınaya yakalanıp Aydonar bölgesinde kazazede olduğu, geminin hamulesi olup karaya çıkartılan malzemelerin ve her nevi alet edevatın teslimine görevli memur yanaşmasada, Rus orta elçisi ahidnâme gereğince eşyanın teslimini talep etmiştir.

88 BOA. C.HR.50-2481.

89 BOA. C.BH.133-6446.

90 BOA. C.HR.160-7955., H.1217 (M.1803), Rusya tebaasından olan Mileke Kalu adlı kaptanın, Mısır'da bulunan Reşid mütesellimi İbrahim Efendi tarafından çalışması için zorla tutulduğu, Reşid'den Abahor 
sigorta vazifesini üzerine almıştır. Özellikle XIX. yüzyılın ikinci yarısıyla birlikte deniz ticaret hacminin artması ve gelişen ticaret ağlarına paralel olarak sigortacılık alanında önemli gelişmeler yaşanmıştır. Bu noktada Osmanlı karasularında faaliyet gösteren gemiler sigorta şirketleri tarafından sigortalanmış ve olası bir kazanın tazmininde sigorta şirketleri de sorumluluk almıştır. ${ }^{91}$

Malların zararının karşılanması dışında devletin diğer bir sorumluluk alanı da kazazede olan gemide hayatlarını kaybeden kişilerin yakınlarına ya da yaralı olarak kurtulan kişilere sağlanacak desteklerdir. Bu noktada karşımıza ilk olarak, batan gemide hayatını kaybeden kişilerin yakınları çıkmaktadır. Gemi kazasında hayatını kaybeden kişinin evlatları varsa devlet hayatını kaybeden kişinin geçmişe dönük maaşlarını evlatlarına ödemiştir. Bazı durumlarda ise ölen kişinin devletten alacağı olmamasına rağmen geride kalan kız kardeşine dahi ödenek sağlanmıştır. Bu husus ayrıca yardıma muhtaç kadınların mağdur edilmemesi itibariyle sosyal devlet aracı üzerinden de yorumlanabilir.92 Bunun dışında kazada hayatını kaybeden kişinin mahlûl (boşalan) olan (teknik beceri gerektiren) görevi genellikle kişinin evlatlarına babası gibi işini iyi yapacağı düşünülerek verilmişse de kimi zaman görev birinci dereceden yakını olmayan kayınbiraderi gibi akrabalarına da verilmiştir. ${ }^{93}$

Şayet, kişi kazadan yaralı kurtulmuşsa ve hayatını idame ettirecek gücü ve kudreti kendinde bulamıyorsa, gemisinin nerede kazazede olduğunu, kendisinin bundan ne derecede yaralandığını anlatarak, devletten yardım istemiştir. Devlet genel prensip olarak kişinin doğruyu söyleyip söylemediğini anlamak için sercerrahı görevlendirip, bahsedildiği gibi kişinin yaralı olup olmadığını, hayatını idame ettirme durumunu yazmasını istemiştir. Sercerrahın raporu doğrultusunda kazazede olan gemiden yaralı olarak kurtulan kişiye gerekli olan destek sağlanmıştır. ${ }^{94} \mathrm{Bu}$ gibi çeşitli des-

denen yere zorla üç sefer yaptırılıp, üçüncü seferinde Abahor'da kazazede olduğu, kaptanın cerim türü kayık (Nil nehri üzerinde kullanılan kayık) bahası olan 2800 ve üç seferin navlun 1500 kuruş olmak üzere toplamda 4300 kuruş verilmesini mütesellimden taraf ettiğini ancak mütesellimin parayı vermediği, bunun üzerine kaptanın Reşid'de buluna Nemçe konsolos vekiline müracaatta bulunduğu, bahsi geçen paranın Misır'da bulunan Rus konsolosuna teslim edilmesini, İstanbul'da bulunan Rus elçisi talep etmiştir. Bu talep karşısında yapılmış olan mukavele ne gerektiriyorsa onun yapılması emredilmiştir.

91 BOA. C.HR.152-7591., H.1270 (M.1853), Avusturya Devleti tüccarlarına ait ve Avusturya sigortası tarafından sigortalanmış iki adet geminin Karadeniz'de kazazede olduğu, sigortanın İstanbul'da yerleşik olarak bulunan Mösyö Parvo adlı vekil tarafından Cozepo Karsiye adlı kişi Bolu ve İzmit bölgelerine işi takip etmesi için gönderilmiştir.

92 BOA. C.BH.199-9330., H.1193 (M.1779), Bıçakçızade Mehmet Kaptan adlı kişinin Karadeniz’de kazazede olan gemide vefat ettiği, kaptanın 450 kuruş borcuna, kardeşi Rabia Hatunun kefil olduğu, bu sebeple Rabia Hatunun rencide ve tazyike uğradığı belirtilip, vefat eden kişilerin geçmişten kalan maaşlarının merhameten çocuklarına verildiği ifade edilmiştir. Bu noktada kaptanın H.1192 Muharreminden Ramazanına kadar 600 kuruş salyanesi kaldığı belirtilmiştir, Yapılan inceleme sonucunda müteveffanın H.1191 senesinden salyanesini aldığ merhameten kaptanın kardeşine 150 kuruş verilmiştir.

93 BOA.AE.SABH-I 165-11021., H.1198 (M.1783), bir kişi, Cebehane-i Âmire'de neccar olan eniştesinin Karadeniz'de (Bahr-i Siyah) batan gemide vefat ettiğini bu nedenle mahlûl olan görevin kendisine verilmesini rica etmiştir.

94 BOA. C.BH.17-806., H.1185 (M.1771), İbrahim adlı kaptan, Karadeniz'de ince donanmada bir kancabaş gemisiyle Tolcı savaşına katılıp kafirlerle savaştığını, savaş sırasında gemisinin battığını ve kendisine de çifte kurşun isabet edip, baldırından şiddetli bir yaralanma geçirdiğini ifade etmiştir. İbrahim Kaptan durumunun iyi olmadığını belirterek kendisine yetecek (kifaf) bir ekmek (nan) parası verilmesini talep etmiştir. Talep üzerine kişinin gerçekten yaralanıp yaralanmadığına Sercerrah tarafından bakılmasına ve buna göre maaşın bağlanmasına karar verilmiştir. Sercerrah yaptığ incelemede, kişinin sağ kalçasına iki kurşun isabet edip yaralandığını belirtmiş ve kişiye tekaütlüğü bağlanmıştır. 
teklerin dışında kaza geçiren gemiden sağ olarak kurtulan kişilere, rütbelerine ve görevlerine göre çeşitli miktarda ihsanda bulunulması yöneticiler tarafindan uygun görülmüştür. ${ }^{95}$

Sorumluluk konusunda devletin, müttefik devletlerin tebaasına karşı tutumu da oldukça dikkat çekicidir. Yaşanan bir kaza sonrası kazadan kurtulup karaya çıkan kişileri İslam hukukuna da uygun olarak ${ }^{96}$ devletin misafiri olarak görülmüş ve bu kişilerin uygun mahallere yerleştirilmesi ilgili görevli ve yöneticilere tembihlenmiştir. ${ }^{97}$ Ayrıca kazazede olan gemilerdeki kişilerin kurtarılmasında yararlılık gösteren kişilere de Müslim-Gayrimüslim fark etmeksizin onore edilmek için devlet tarafindan madalya takdiminde bulunulmuştur. ${ }^{98}$

\section{Sonuç}

Osmanlı Devleti'nde fırtına, savaş gibi nedenlerle batan gemiler için genellikle kazazede ifadesi kullanılmıştır. Kazazede olarak adlandırılan gemilerden kalan malzemelerin denizden çıkartılması ve malzemelerin İstanbul'a gönderilmesi devletin kaza sonrasında üzerinde durduğu en önemli konudur. İlk olarak kazazede olarak ifade edilen batığın bulunduğu bölgenin yöneticileri geminin batma nedenini ve genel durumu İstanbul'a bildirmiştir. Devlet gelen haber üzerine batan gemi veya gemilerden kalan malzemelerin toplanıp uygun gemilerle İstanbul'a teslimini sağlamak üzere donanmada görevli kaptan veya memurların sorumluğunda, sömbeki adı verilen dalgıçları çeşitli alet ve edevatlarıyla hızlıca batık mahalline göndermiştir. Kimi zaman görevlilerden önce bölge halkı batığa ait malzemeleri çıkartmış olsa da kazanın üstünden uzunca bir süre geçmiş olsa bile devlet batıklara ait malzemenin izini sürmüş ve izinsiz bir şekilde malzemeleri çıkartan ve satan kişileri cezalandırma yoluna gitmiştir.

Batıklardan çıkartılan malzemeleri askeri ve ticari malzemeler olarak iki gruba ayırabiliriz. Askeri malzemelerin içerisinde uzunca süre su altında dayanabilen lenger, top ve çeşitli metaller önemli bir yer tutarken, ticari malzemeler çok daha geniş yelpazede olup, zeytinyağ 1 , buğday gibi gıda malzemeleri dışında iplik, bez, çeşitli türden kumaş ve hatta kum saati gibi birçok malzeme mevcuttur.

Donanmaya ait gemilerin malzemeleri denizden çıkarıldığ üzere İstanbul'a nakledilmiş, tüccara ait gemiz veya malzemeler ise tespit edilen sahiplerine teslim edilmiştir. Ancak kapitülasyonların etkisini gösterdiği XIX. yüzyılın başlarından itibaren batıklardan çıkartılan malzemeler konusunda yabancı devlet temsilcilerinin müdahaleleri söz konusu olmuştur. Osmanlı karasularında faaliyet gösteren kaptanlar ve tacirler ilk zamanlar denizden çıkartılan malzemelerin kendilerine teslimi konusunda devlete müracaat ederken, XIX. yüzyılın başlarından itibaren Osmanlı topraklarında bulunan elçiler ve konsoloslara müracaat etmişlerdir. $\mathrm{Bu}$

95 BOA. C.BH.60-2828., H.1208 (M.1793), Hüseyin Kaptan adlı kişinin gemisi zahire nakli için Karadeniz’e açılmış ancak Kilyos civarında kazazede olmuştur. Tersane ricali tarafından kazazede gemide olup karaya çıkan gemi mürettebatına toplam 600 kuruş atiye verilmesi uygun görülmüştür. Verilecek olan atiyenin miktarı, Reis-i Evvel 60 kuruş, Reis-i Sani 40 kuruş, Reis-i Salis 30 kuruş, gemi ağası 30 kuruş ve 20 neferin her birine 20 kuruştur.

96 İdris Bostan, Osmanlı Akdenizi, Küre Yayınları, İstanbul, 2017, s.300-301.

97 BOA. C.HR.24-1151., H.1214 (M.1799), Rusya tarafindan Akdeniz'de bulunan donanmaya katılmas1 için gönderilen bir fırkateynin Kili Kalesi önünde kazazede olduğu, batan gemide bazı neferatın öldüğü bazılarının ise karaya çıkabildiğini, karaya çıkanların devletin misafiri olduğundan bu kişilerin bölgede uygun mahallere yerleştirilmesi istenmiştir.

98 BOA. C.HR.13-609., H.1281 (M.1865), Köstence Limanı karşısında batmakta olan gemiden dört kişiyi kurtaran Avusturya tebaasından bir kaptana gayretinden ötürü madalya verilmiştir. 
kişiler devletlerine verilen ahidnâmelere dayanarak gerek yabancı tacirler gerekse berat ve patent gibi çeşitli yollarla himaye kazanmış olan gerçekte Osmanlı tebaası olan tacirlere ait batıklardaki malzemelerin takibine başlamışlardır. Devlet verilen ahidnâmelere sadık kalarak gerekli incelemeleri yaptıktan sonra malzemelerin verilmesini görevlilere emretmiştir.

$\mathrm{Bu}$ konuların dışında kazazede olarak adlandırılan gemilerde vefat eden kişilerin yakınlarına ya da sağ ve yaralı olarak kurtulan kişilere gerekli maddi destek devlet tarafindan sağlanmıştır. Ayrıca kazazede olan gemilerdeki kişilerin kurtarılmasına katkıda bulunan kişileri de onore etmek için madalya takdiminde bulunulmuştur. Bu noktada devletin yapılması gereken bütün sorumluklarını gücü ve imkânı dahilinde yerine getirdiğini rahatlıkla söyleyebiliriz.

\section{KAYNAKÇA}

\section{I- ARŞIV BELGELERI}

\section{T.C. CUMHURBAŞKANLIĞI DEVLET ARŞIVLERİ BAŞBAKANLIĞI OSMANLI} ARŞIVİ (BOA.)

\section{ALI EMİI:}

Sultan I. Abdülhamid (AE.SABH-I): 165-11021, 236-15763.

Sultan III. Selim (AE.SSLM-III): 37-2129, 116-7074.

\section{CEVDET:}

Askeriye (C.AS): 71-3333, 1204-53925, 1218-54653.

Bahriye (C.BH): 2-46, 2-60, 2-67, 7-317, 17-806, 21-1006, 29-1380, 36-1686, 60-2828, 632970, 84-4005, 84-4017, 86-4136, 97-4667, 99-4751, 102-4906, 103-4972, 104-5033, 105-5096, 111-5384, 123-5978, 123-5981, 124-6014, 133-6446, 150-7164, 152-7252, 199-9330, 201-9425, 206-9622, 213-9926, 219-10198, 220-10234, 246-11377, 258-11927, 270-12490, 273-12612.

Hariciye (C.HR): 4-193, 7-311, 13-609, 18-864, 24-1151, 25-1240, 50-2481, 60-2983, 954716, 98-4873, 152-7591, 160-7955.

\section{II-KAYNAK ESERLER}

Evliya Çelebi, Evliya Çelebi Seyahatnâmesi; İstanbul, 1.Cilt-2.Kitap, (Yay. Haz. Seyit Ali Kahraman-Yücel Dağlı), Yapı Kredi Yayınları, İstanbul, 2004.

Evliya Çelebi, Seyahatnâme (Akdeniz Adaları ve Girit Fethi), (Yay. Haz. İsmet Parmaksızoğlu), Kültür ve Turizm Bakanlığı Yayınları, Ankara, 1983.

\section{III-ARAŞTIRMA ESERLER}

AYDIN, Yusuf Alperen, Sultanın Kalyonları Osmanlı Donanmasının Yelkenli Savaş Gemileri (1701-1770), Küre Yayınları, İstanbul, 2011.

BAĞIŞ, Ali İhsan, Osmanlı Ticaretinde Gayri Müslimler, Turhan Kitabevi, Ankara, 1983.

BERKES, Niyazi, Türkiye İktisat Tarihi, Yapı Kredi Yayınları, İstanbul, 2013.

BOSTAN, İdris, Adriyatik’te Korsanlık Osmanlılar, Uskoklar, Venedikler 1575-1620, Timaş Yayınları, İstanbul, 2009. 
BOSTAN, İdris, Osmanlı Akdenizi, Küre Yayınları, İstanbul, 2017.

BOSTAN, İdris, Osmanlı Bahriye Teşkilâtı: XVII. Yüzyılda Tersâne-i Âmire, T.T.K., Ankara, 2003.

BOSTAN, İdris, Osmanlılar ve Deniz (Deniz Politikaları-Teşkilât-Gemiler), Küre Yayınları, İstanbul, 2017.

BOZKURT, Gülnihal, Azınlık İmtiyazları - Kapitülasyonlardan Tek Hukuk Sistemine Geçiş, ATAM., Ankara, 1998.

BULUNUR, Kerim İlker, "16. Yüzyllda Osmanlı Imparatorluğu'nda Deniz Taşımacılığı: Navlun ve İskerçe Sözleşmeleri”, History Studies, Volume 6-Issue 3, Nisan 2014.

FAROQHI, Suraiya, "Krizler ve Değişim 1590-1699”, Osmanlı İmparatorluğu'nun Ekonomik ve Sosyal Tarihi, C.2, (Edt. Halil İnalcık-Donald Quataert), Eren Yayıncılık, İstanbul, 2006.

GENCER, Ali İhsan, Bahriye'de Yapılan Islâhât Hareketleri ve Bahriye Nezâreti'nin Kuruluşu (1789 - 1867), T.T.K., Ankara, 2001.

GENÇ, Mehmet, Osmanıı İmparatorluğunda Devlet ve Ekonomi, Ötüken, İstanbul, 2014.

KARAL, Enver Ziya, Selim III'ün Hat-tı Hümayunları Nizamı Cedit 1789-1807, T.T.K., Ankara, 1988. 2018.

KOCAOĞLU, Burak, Osmanlı Devleti'nde Cizye Vergisi, Berikan Yayınevi, Ankara,

KÜTÜKOĞLU, Mübahat, Balta Limanı'na Giden Yol Osmanlı - İngiliz İktisâdî Münâsebetleri (1580 - 1850), T.T.K., Ankara, 2013.

KÜTÜKOĞLU, Mübahat, "Osmanlı İktisadî Yapısı", Osmanlı Devleti Tarihi, C.2, (Edt. Ekmeleddin İhsanoğlu), IRICA, İstanbul, 1999.

KÜTÜKOĞLU, Mübahat, Osmanlı'nın Sosyo-Kültrüel ve İktisâdî Yapısı, T.T.K., Ankara, 2018.

MANTRAN, Robert, 17. Yüzyılın İkinci Yarısında İstanbul, C.II, (Çev. M. Ali KılıçbayEnver Özcan), T.T.K., Ankara, 1990.

ÖZDEMİR, Şenay, "Osmanlı Denizciliğinde Gemi Kazaları ve Dalışlar”, OTAM, S.19, Ankara, 2006.

PAKALIN, Mehmet Zeki, Osmanlı Tarih ve Deyimler Sözlüğü, C.2, Milli Eğitim Basımevi, İstanbul, 1983.

PANZAC, Daniel, Osmanlı Donanması (1572-1923), (Çev. Ahmet Maden-Sertaç Canpolat), İş Kültür Yayınları, İstanbul, 2018.

QUATERT, Donald, “19. Yüzylla Genel Bakış: Islahatlar Devri 1812-1914”, Osmanlı İmparatorluğu'nun Ekonomik ve Sosyal Tarihi, C.2, (Edt. Halil İnalcık-Donald Quataert), Eren Yayınc1lık, İstanbul, 2006

UZUNÇARŞILI, İsmail Hakkı, Osmanlı Devleti’nin Merkez ve Bahriye Teşkilâtı, T.T.K., Ankara, 1988.

ZORLU, Tuncay, Osmanlı ve Modernleşme III. Selim Dönemi Osmanlı Denizciliği, Timaş Yayınları, İstanbul, 2014. 


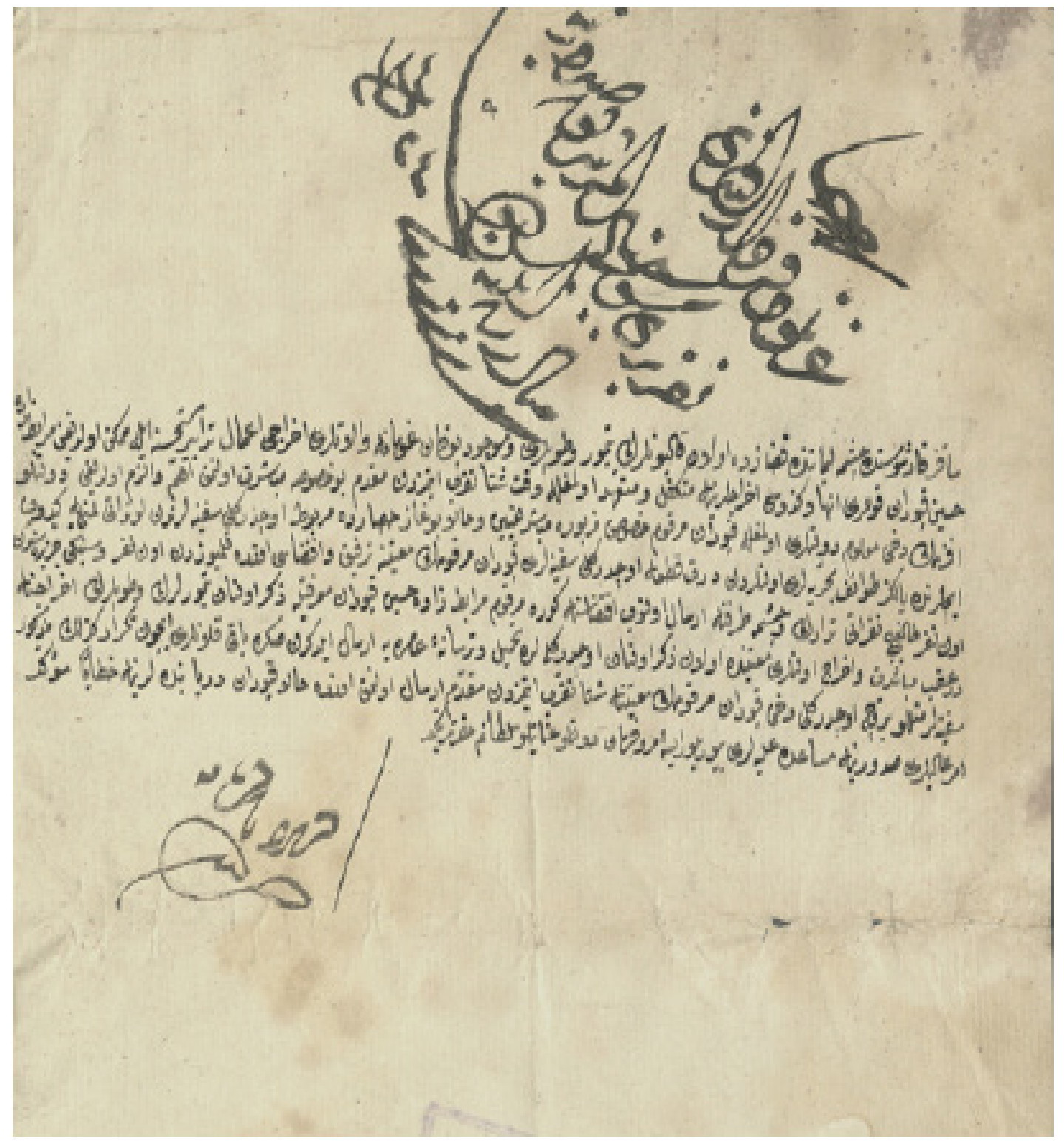

Ek-1. Sakız Adası karşısında, Çeşméde kazazede olan kalyonların, lenger, top ve gomona aletlerinin için çıkartılmasına dair. (BOA. C.BH.213-9926) 
Tarih ve Gelecek Dergisi, Ağustos 2019, Cilt 5, Sayl 2

Journal of History and Future, August 2019, Volume 5, Issue 2 http://dergipark.gov.tr/jhf

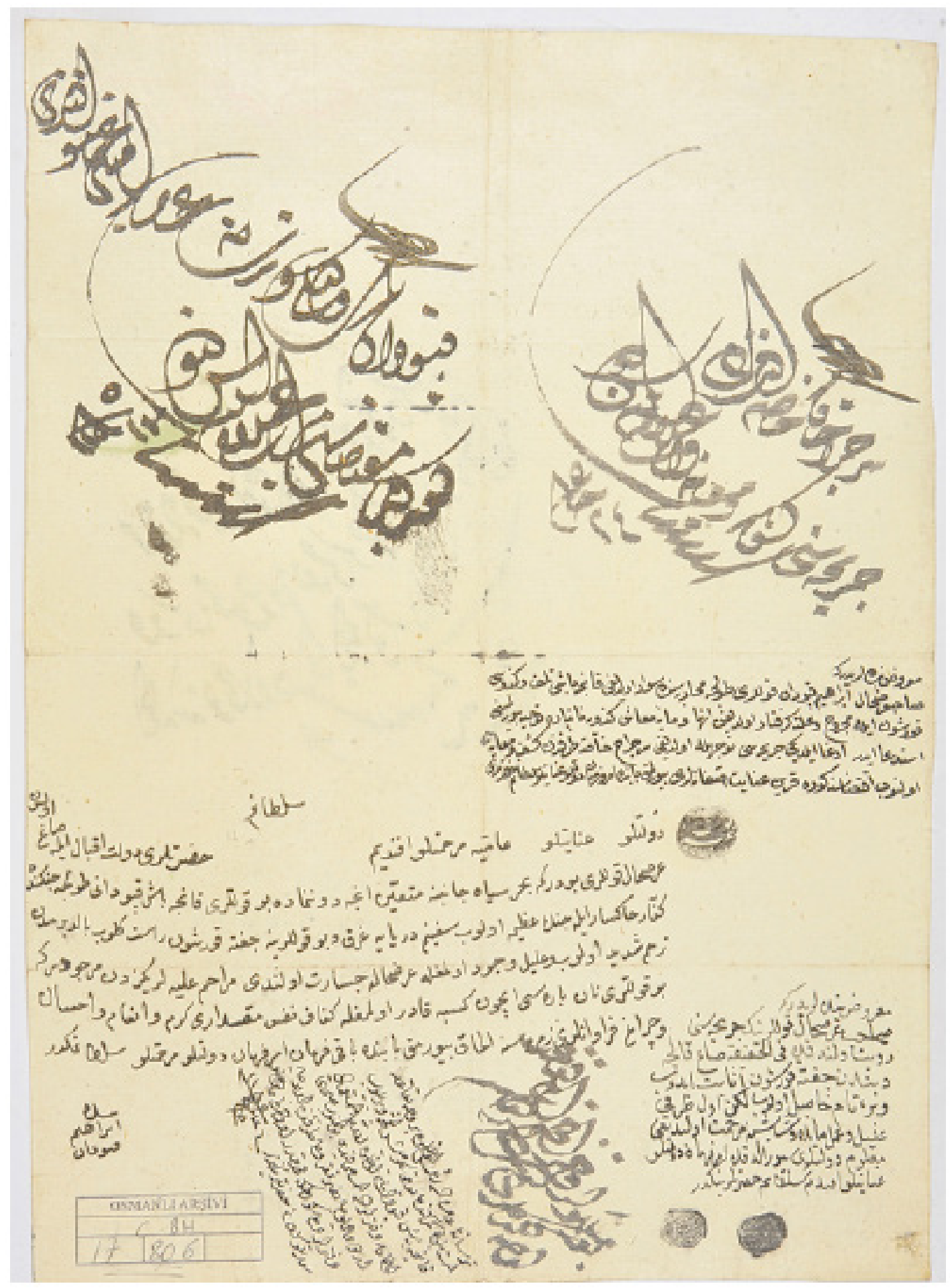

Ek-2. Savaş sırasında gemisi batan ve kendiside yaralanan kaptana maaş bağlanmasına dair. (BOA. C.BH.17-806) 